\title{
Effect of pawpaw (Carica papaya) leaf meal and dietary enzymes on broiler performance, digestibility, carcass and blood composition
}

\author{
Olugbenga David Oloruntola ${ }^{1,2^{*}}$ Simeon Olugbenga Ayodele ${ }^{2}$ \\ Deborah Adebukola Oloruntola ${ }^{3}$
}

\section{Keywords}

Broiler chickens, animal feeding, papayas, enzymes, animal performance, Nigeria

Submitted: 8 July 2017

Accepted: 12 July 2018

Published: 29 October 2018

DOI: $10.19182 /$ remvt.31640

\begin{abstract}
Summary
Exogenous enzymes and phytogenic feed additives are proposed as alternatives to antibiotic growth promoters in poultry production. This study assessed the effect of pawpaw leaf meal (PLM) inclusion and enzyme (E) supplementation in the diet of broiler chickens. In total, 288 Arbor-Acre day-old broiler chickens were used. Four diets were formulated to be isocaloric and isonitrogenous: diet 1, control ( $0 \%$ PLM, $0 \% \mathrm{E})$, diet $2(0 \% \mathrm{PLM}, 0.05 \% \mathrm{E})$, diet $3(5 \%$ PLM, 0\% E), and diet 4 (5\% PLM, 0.05\% E). Each diet was replicated six times with 12 chickens in each batch. E improved $(p<0.05)$ the body weight gain at three weeks. The dry matter (DM), crude protein (CP), ether extract and ash digestibility were improved $(p<0.05)$ with $E$, whereas PLM inclusion produced $(p<0.05)$ an increase in DM and CP digestibility. The Ex PLM effect was significant $(p<0.05)$ for DM and CP digestibility. E improved $(p<0.05)$ the slaughter weight and reduced the liver weight. Platelets varied across diets and increased $(p<0.05)$ with enzyme supplementation. E reduced $(p<0.05)$ low-density lipoproteins $(\mathrm{LDL})$, whereas PLM reduced $(\mathrm{p}<0.05)$ cholesterol and LDL. In conclusion, the association of E and PLM improved chicken growth, and E or PLM inclusion should benefit chicken health.
\end{abstract}

- How to quote this article: Oloruntola O.D., Ayodele S.O., Oloruntola D.A., 2018. Effect of pawpaw (Carica papaya) leaf meal and dietary enzymes on broiler performance, digestibility, carcass and blood composition. Rev. Elev. Med. Vet. Pays Trop., 71 (3): 121-129, doi: 10.19182/remvt.31640

\section{INTRODUCTION}

Intensive poultry production in developing countries could be further enhanced through feeding strategies that promote feed utilization in relation to bird performances. Before 2003 in the United Kingdom, the inclusion of antibiotics as growth promoters in animal

\footnotetext{
1. Animal Science Department, Adekunle Ajasin University, Akungba Akoko, Nigeria.

2. Department of Agricultural Technology, The Federal Polytechnic, Ado Ekiti, Nigeria.

3. Department of Microbiology, The Federal University of Technology, Akure, Nigeria.

* Corresponding author

Tel: +234 803584 16 26; Email: oloruntoladavid@gmail.com
}

feed was widely adopted following the reported growth stimulation observed (Bedford, 2000). Thus according to Falçao-e-Cunha et al. (2007), antibiotics have the ability to decrease feed usage per production unit with concomitant increase in production performance. This is in addition to the fact that antibiotics can help reduce the disease burden, inhibit pathogenic microorganisms, and reduce microbial toxic metabolites, epithelium turn over, intestinal motility and bacterial deconjugation of bile salt (Falçao-e-Cunha et al., 2007). However, the ban on the use of antibiotics in animal feed has fueled the search for alternative animal growth promoters in the form of enzyme supplementation (Garcia et al., 2008) and phytogenic feed additives (Oloruntola et al., 2018). Enzyme supplementation has been reported to improve changes in the intestinal environment, including the viscosity of the digesta, which may promote contact among nutrients, endogenous enzymes and absorptive mucosae, thus enhancing the usage of the diet by the concerned animal (Lázaro et al., 2003; Mateos et al., 2010). 
Phytogenic feed additives are gradually gaining prominence in animal feeding to improve their performance and boost their immune response (Oloruntola et al., 2016b). These products include pawpaw whose leaf has been previously identified by Oloruntola et al. (2018) as a natural source of papain, chymopapain A and B, and papaya peptidase A. Papain is proteolytic and thus capable of enhancing protein digestion (Oloruntola et al., 2018). In addition, the papaya leaf contains broad-spectrum phytochemicals including alkaloids and phenols. Phenolic compounds have high antioxidant activity and free radical scavenging capacity, with the mechanism of inhibiting enzymes responsible for reactive oxygen species production (Kahkonen et al., 2001).

The antibacterial, antifungal, antiviral, neuroprotective and antifertility activities of papaya have also been documented (Kadiri et al., 2016). It is conceivable that the nutritive and phytogenic potentials of the papaya leaf could be used as a growth promoter in broiler chicken feed. Hematological and serum biochemistry assay of livestock can show the physiological disposition of animals to nutrition, meaning that they can be a reflection of the physiological responsiveness of animals to feed and feeding (Oloruntola et al., 2016b). In addition, deviation in the relative internal organ weight of animals has been reported to be indicative of a possible response of their internal organs to toxins in their feed (Ayodele et al., 2016). Therefore, the assessment of the effect of enzymes and pawpaw leaf meal on the performance, carcass, physiological status of the animals, especially the hematology and serum biochemistry, is important. The objective of this study was thus to assess the effect of exogenous enzymes and pawpaw leaf meal inclusion on the performance and physiological status of broiler chickens.

\section{MATERIALS AND METHODS}

\section{Experimental site, animal management and design}

The experiment was carried out at the Teaching and Research Farm Department of the Agricultural Technology, The Federal Polytechnic, Ado Ekiti, Nigeria. In total, 288 Arbor-Acre one-day-old unsexed broiler chicks were randomly distributed into 24 pens of 12 birds each. The pens were allotted to four dietary treatment groups arranged in six replications. The experimental design was of a completely randomized design in a $2 \times 2$ factorial arrangement, i.e. diets with 0 and $50 \mathrm{~g} /$ $\mathrm{kg}$ pawpaw leaf meal (PLM), and diets with 0 and $0.5 \mathrm{~g} / \mathrm{kg}$ enzymes added after feed manufacturing. PLM was included in diets 3 and 4 by replacing palm kernel cake and soybean meal (Table I).

The birds were placed on wood shaving litter in controlled pens. The temperature was controlled within the range of $32 \pm 2{ }^{\circ} \mathrm{C}$ on days 1 to 7 , then reduced by $2^{\circ} \mathrm{C}$ on each successive week and thereafter maintained at $28 \pm 2^{\circ} \mathrm{C}$ until the end of the experiment. In the first week, the birds were exposed daily to 23 hours of lighting and 1 hour of darkness, and thereafter to 18 hours of lighting and 6 hours of darkness until the end of the experiment. The birds were fed their respective experimental diets and water ad libitum for six weeks.

\section{Experimental diets}

The enzyme used was a commercial complex (Bioenzyme PH) whose composition is presented in Table II. Fresh pawpaw leaves were harvested from the Teaching and Research Farm at about 6:00 GMT, chopped into smaller pieces, air dried for 14 days, hammer milled and kept in an airtight container before use. The pawpaw leaf meal was analyzed in triplicate for proximate composition using an AOAC method (1990) (Table III). PLM was further analyzed for alkaloids (Harbone, 1973), saponins (Shad et al., 2013), tannins (Van-Burden and Robinson, 1981) and flavonoids (Shad et al., 2013). Phytates and oxalates were determined according to Wheeler and Ferrel (1971), and Day and Underwood (1986), respectively.
Table I

Gross composition of broiler starter diets with/without $5 \%$ pawpaw leaf meal, or with $(+\mathrm{E}) /$ without $(-\mathrm{E})$ enzyme*

\begin{tabular}{|c|c|c|c|c|}
\hline & Diet 1 & Diet 2 & Diet 3 & Diet 4 \\
\hline Enzyme & $-E$ & $+\mathrm{E}$ & $-E$ & $+\mathrm{E}$ \\
\hline Pawpaw leaf meal & 0.00 & 0.00 & 5.00 & 5.00 \\
\hline Maize (\%) & 50.00 & 50.00 & 50.00 & 50.00 \\
\hline Groundnut cake (\%) & 10.50 & 10.50 & 10.50 & 10.50 \\
\hline $\begin{array}{l}\text { Soybean meal } \\
(42 \% \text { CP) }(\%)\end{array}$ & 25.00 & 25.00 & 23.00 & 23.00 \\
\hline Fish meal $(72 \%$ CP) $(\%$ & 4.00 & 4.00 & 4.00 & 4.00 \\
\hline Palm kernel cake (\%) & 6.00 & 6.00 & 3.00 & 3.00 \\
\hline Bone meal (\%) & 3.00 & 3.00 & 3.00 & 3.00 \\
\hline Oyster shell (\%) & 0.50 & 0.50 & 0.50 & 0.50 \\
\hline Premix** $(\%)$ & 0.25 & 0.25 & 0.25 & 0.25 \\
\hline Methionine (\%) & 0.30 & 0.30 & 0.30 & 0.30 \\
\hline Lysine $(\%)$ & 0.15 & 0.15 & 0.15 & 0.15 \\
\hline Salt (\%) & 0.30 & 0.30 & 0.30 & 0.30 \\
\hline \multicolumn{5}{|l|}{ Chemical composition } \\
\hline Crude protein (\%) & 23.92 & 23.90 & 23.82 & 23.83 \\
\hline Crude fiber (\%) & 3.19 & 3.21 & 3.77 & 3.76 \\
\hline Crude fat $(\%)$ & 4.20 & 4.21 & 4.15 & 4.14 \\
\hline \multicolumn{5}{|l|}{ Calculated composition } \\
\hline $\mathrm{Ca}(\% \mathrm{DM})$ & 1.56 & 1.56 & 1.55 & 1.55 \\
\hline Available P (\% DM) & 0.72 & 0.72 & 0.71 & 0.71 \\
\hline ME (kcal/kg) & 2,914 & 2,914 & 2,920 & 2,920 \\
\hline Methionine (\% DM) & 0.57 & 0.57 & 0.54 & 0.54 \\
\hline Lysine (\% DM) & 1.31 & 1.31 & 1.26 & 1.26 \\
\hline
\end{tabular}

* Enzymes at $0.5 \mathrm{~g} / \mathrm{kg}$ feed were added after feed manufacturing.

** Per kilogram of diet (mg): vitamin A (as all-trans retinol), $3.6 \mathrm{mg}$; cholecalciferol, $0.09 \mathrm{mg}$; vitamin $\mathrm{E}$ (as d- $\alpha$ - tocopherol), $44.7 \mathrm{mg}$; vitamin $\mathrm{K} 3,2 \mathrm{mg}$; thiamine, $2 \mathrm{mg}$; riboflavin, $6 \mathrm{mg}$; pyridoxine hydrochloride, $5 \mathrm{mg}$; vitamin B12, $0.2 \mathrm{mg}$; biotin, $0.1 \mathrm{mg}$; niacin, $50 \mathrm{mg}$; D-calcium pantothenate, $12 \mathrm{mg}$; folic acid, $2 \mathrm{mg}$; $\mathrm{Mn}$, $80 \mathrm{mg}$; Fe, $60 \mathrm{mg}$; Cu, 8 mg; I, $1 \mathrm{mg}$; Co, $0.3 \mathrm{mg}$; Mo, $1 \mathrm{mg}$

\section{Table II}

Composition of Bioenzyme PH

\begin{tabular}{|c|c|c|}
\hline Enzyme & Composition/kg & Activity \\
\hline Cellulase & 700,000 UA & $\begin{array}{l}\text { Breaks down feed fiber } \\
\text { into glucose. }\end{array}$ \\
\hline$\alpha$-amylase & 800,000 UA & $\begin{array}{l}\text { Converts starch into } \\
\text { glucose and maltose. }\end{array}$ \\
\hline Phytase & 1,200 FTU & $\begin{array}{l}\text { Releases phosphorus which } \\
\text { is bound as phytate. }\end{array}$ \\
\hline Protease & $8,000,000$ UP & Hydrolyzes proteins. \\
\hline$\beta$-glucanase & 300,000 UBG & $\begin{array}{l}\text { Breaks down glucans which } \\
\text { are polysaccharides. }\end{array}$ \\
\hline Lipase & 20,000 UI & $\begin{array}{l}\text { Breaks down feed oil and fat, } \\
\text { and produces energy. }\end{array}$ \\
\hline Xylanase & 500,000 UX & $\begin{array}{l}\text { Converts feed xylan into } \\
\text { xylose by hydrolysis. }\end{array}$ \\
\hline
\end{tabular}

Source: Biomix, Sabaneta, Colombia 
Table III

Proximate and phytochemical composition of pawpaw leaf meal using AOAC 1990's method

\begin{tabular}{lc} 
Components & Concentration \\
\hline Crude protein $(\%)$ & 26.14 \\
Crude fiber $(\%)$ & 16.05 \\
Ash $(\%)$ & 1.64 \\
Ether extract $(\%)$ & 5.40 \\
Nitrogen-free extract $(\%)$ & 40.95 \\
Alkaloid $(\mathrm{g} / \mathrm{kg})$ & 28.10 \\
Saponin $(\mathrm{g} / \mathrm{kg})$ & 16.90 \\
Tannin $(\mathrm{g} / \mathrm{kg})$ & 0.01 \\
Flavonoid $(\mathrm{g} / \mathrm{kg})$ & 63.00 \\
Phytate $(\mathrm{g} / \mathrm{kg})$ & 20.18 \\
Oxalate $(\mathrm{g} / \mathrm{kg})$ & 6.11
\end{tabular}

Four isocaloric and isoproteinacious experimental diets were formulated. They were designated as diet 1 or control (0\% PLM, 0\% E), diet 2 (0\% PLM, 0.05\% E), diet $3(5 \%$ PLM, 0\% E) and diet 4 (5\% PLM, $0.05 \%$ E) (Table I). Diets 1 and 3 were not enzyme supplemented but had pawpaw leaf meal inclusion at $0 \%$ and $5 \%$ level, respectively, whereas diets 2 and 4 were enzyme supplemented at the rate of $0.05 \%$ but had PLM inclusion at $0 \%$ and $5 \%$ level, respectively. The calculated composition of experimental diets at starter (1 to 21 days of age) and grower-finisher (22 to 35 days of age) phases are shown in Tables I and IV, respectively, and were formulated to meet the nutritional requirements of broiler chickens.

\section{Performance and apparent digestibility}

The birds were weighed individually at the beginning of the trial and weekly. Feed consumption and mortality were recorded daily during the whole experiment. The weekly final weight gain was determined by subtracting the initial weight of birds from the final weight. The feed conversion ratio (FCR) was calculated as the ratio of feed consumed to weight gain, whereas the mortality was calculated as the number of deaths per treatment per day. Five birds were randomly selected from each replicate at 35 days of age, housed individually in a metabolism cage for fecal collection and apparent digestibility determination of dry matter (DM), crude protein (CP), ether extract (EE) and ash based on procedures described by Vogtman et al. (1975). Feed was supplied ad libitum; after the first three days of adaptation, feed intake and feces were recorded during four days. Droppings were collected twice daily, thoroughly mixed and weighed. Aliquots from each day samples were frozen at $-20^{\circ} \mathrm{C}$ and bulked at the end of the fourth day. Thereafter, the bulked samples were weighed and dried in a forced air circulation oven at $60^{\circ} \mathrm{C}$ for 12 hours. The dried droppings were later ground ( $0.5 \mathrm{~mm}$ screen) and analyzed for proximate composition. Apparent digestibility were expressed as (feed intake - fecal $) \times 100 /$ feed intake.

\section{Bird slaughtering, blood collection, carcass and organ evaluation}

At 42 days old, three birds from each replicate were randomly selected, tagged, starved overnight, weighed and slaughtered by cutting the jugular veins, allowing blood to flow freely into a bottle containing ethylene diaminetetra acetic acid (EDTA), and a plain bottle for hematology and serum chemistry analysis, respectively. The serum was separated from the blood samples and frozen at $-20^{\circ} \mathrm{C}$

\section{Table IV}

Gross composition of broiler finisher diets with/without $5 \%$ pawpaw leaf meal, or with $(+E) /$ without $(-E)$ enzyme *

\begin{tabular}{|c|c|c|c|c|}
\hline & Diet 1 & Diet 2 & Diet 3 & Diet 4 \\
\hline Enzyme & $-E$ & $+\mathrm{E}$ & $-E$ & $+\mathrm{E}$ \\
\hline Pawpaw leaf meal & 0.00 & 0.00 & 5.00 & 5.00 \\
\hline Maize (\%) & 60.00 & 60.00 & 60.00 & 60.00 \\
\hline Groundnut cake (\%) & 6.50 & 6.50 & 7.0 & 7.0 \\
\hline $\begin{array}{l}\text { Soybean meal } \\
(42 \% \text { CP) }(\%)\end{array}$ & 20.00 & 20.00 & 17.50 & 17.50 \\
\hline Fish meal $(72 \%$ CP) (\%) & 3.00 & 3.00 & 3.00 & 3.00 \\
\hline Palm kernel cake $(\%)$ & 6.00 & 6.00 & 3.00 & 3.00 \\
\hline Bone meal (\%) & 3.00 & 3.00 & 3.00 & 3.00 \\
\hline Oyster shell (\%) & 0.50 & 0.50 & 0.50 & 0.50 \\
\hline Premix** (\%) & 0.25 & 0.25 & 0.25 & 0.25 \\
\hline Methionine (\%) & 0.30 & 0.30 & 0.30 & 0.30 \\
\hline Lysine $(\%)$ & 0.15 & 0.15 & 0.15 & 0.15 \\
\hline Salt (\%) & 0.30 & 0.30 & 0.30 & 0.30 \\
\hline \multicolumn{5}{|l|}{ Chemical composition } \\
\hline Crude protein $(\%)$ & 20.04 & 20.06 & 20.02 & 20.01 \\
\hline Crude fiber (\%) & 2.85 & 2.84 & 3.42 & 3.43 \\
\hline Crude fat (\%) & 3.51 & 3.53 & 3.48 & 3.49 \\
\hline \multicolumn{5}{|l|}{ Calculated composition } \\
\hline $\mathrm{Ca}(\% \mathrm{DM})$ & 1.48 & 1.48 & 1.47 & 1.47 \\
\hline Available P (\% DM) & 0.68 & 0.68 & 0.67 & 0.67 \\
\hline $\mathrm{ME}(\mathrm{kcal} / \mathrm{kg})$ & 988 & 2,988 & 3,000 & 3,000 \\
\hline Methionine (\% DM) & 0.51 & 0.51 & 0.50 & 0.50 \\
\hline Lysine (\% DM) & 1.09 & 1.09 & 1.03 & 1.03 \\
\hline
\end{tabular}

* Enzymes at $0.5 \mathrm{~g} / \mathrm{kg}$ were added after feed manufacturing.

** Per kilogram of diet (mg): vitamin A (as all-trans retinol), $3.6 \mathrm{mg}$; cholecalciferol, $0.09 \mathrm{mg}$; vitamin $\mathrm{E}$ (as d- $\alpha$ - tocopherol), $44.7 \mathrm{mg}$; vitamin $\mathrm{K} 3,2 \mathrm{mg}$; thiamine, $2 \mathrm{mg}$; riboflavin, $6 \mathrm{mg}$; pyridoxine hydrochloride, $5 \mathrm{mg}$; vitamin B12, $0.2 \mathrm{mg}$; biotin, $0.1 \mathrm{mg}$; niacin, $50 \mathrm{mg}$; D-calcium pantothenate, $12 \mathrm{mg}$; folic acid, $2 \mathrm{mg} ; \mathrm{Mn}$, $80 \mathrm{mg}$; Fe, 60 mg; Cu, 8 mg; I, 1 mg; Co, 0.3 mg; Mo, 1 mg

$\mathrm{CP}$ : crude protein; DM: dry matter; ME: metabolizable energy

before analysis. Thereafter, the slaughtered chickens were defeathered after scalding in hot water $\left(55-60^{\circ} \mathrm{C}\right)$ for 30 seconds, dressed and eviscerated. The dressed weights were estimated. The internal organs (liver, heart, lung and gizzard) were excised, weighed and expressed as a percentage of the slaughtered weight.

\section{Blood parameter analysis}

The packed cell volume, red blood cells, mean cell hemoglobin, mean corpuscular hemoglobin concentration, mean cell volume, hemoglobin concentration and white blood cells were determined according to Lambs (1981). Total protein, albumin, globulin, cholesterol, high-density lipoprotein, low-density lipoprotein (LDL), bilirubin, and alanine transaminase were determined with Reflectron Plus 8C79 kit (Roche Diagnostic, GonbH Mahnheim, Germany).

\section{Data analysis}

All data on performance, digestibility, blood parameters and carcass evaluation were subjected to analysis of variance from general linear model procedures for complete randomized design with two-enzyme 
levels $\times$ two PLM levels factorial arrangement of treatments. The data were tested for enzyme, PLM, and interaction of enzyme with PLM. When the treatment effect was significant $(p<0.05)$, means were separated with Duncan's multiple range test using SPSS version 20.

\section{RESULTS}

\section{Chemical composition of pawpaw leaf meal, performance of broiler chicken and digestibility of nutrients}

Pawpaw leaf meal contained high crude protein (26.14\%), crude fiber (16.05\%) contents and phytochemicals such as alkaloids, saponins, tannins, flavonoids, phytates and oxalates at reasonable levels (Table III). Table V shows that at three weeks old the body weight (BW) gain of broiler chickens in diet 4 was significantly $(\mathrm{p}<0.05)$ higher than that in the other diets. At six weeks old, the BW gain of birds fed enzyme supplemented diets (diets 2 and 4) was similar but significantly $(\mathrm{p}<0.05)$ higher than that with diets 1 and 3 . Enzyme supplementation significantly $(\mathrm{p}<0.05)$ improved the BW gain at three and six weeks, whereas PLM inclusion increased it $(\mathrm{p}<0.05)$ at six weeks of age. The interaction of enzyme $x$ PLM was not significant $(p>0.05)$ at three and six weeks of age.

Enzyme supplementation (E) numerically improved the feed intake and feed conversion ratio, whereas PLM inclusion numerically improved the feed conversion ratio but decreased the feed intake at both starter and finisher phases. Table VI shows that the apparent digestibility of DM and CP was improved $(\mathrm{p}<0.05)$ in enzyme and/or PLM supplemented diets (diets 2, 3 and 4) compared to control. The ether extract and ash digestibility in birds fed the control diet were similar to those of diet 3 with 5\% PLM, but lower than those of diets 2 and 4. E significantly $(\mathrm{p}<0.05)$ improved DM, CP, EE and ash digestibility, whereas PLM inclusion significantly $(p<0.05)$ increased DM and $\mathrm{CP}$ digestibility. The interaction effect of $\mathrm{E}$ and PLM was significant $(\mathrm{p}<0.05)$ for DM and CP digestibility (Table VI).

\section{Carcass traits, internal organ weight and blood parameters}

Table VII shows the effect of PLM and E on the carcass and relative internal organ weight of broiler chickens. The slaughter weights (SW) of broiler chickens in diets 2 and 4 were similar to those fed diet 3 but higher $(\mathrm{p}<0.05)$ than those fed the control diet. The relative liver weight of broiler chickens fed diets 1 and 4 was similar, but it was significantly $(\mathrm{p}<0.05)$ high in chickens fed diet 3 . E significantly $(\mathrm{p}<0.05)$ improved SW, reduced the liver weight and tended to improve $(\mathrm{p}=0.08)$ the dressed weight (DW), whereas PLM tended to increase $(p=0.06)$ SW. E was not significant $(p>0.05)$ for the dressed weight percentage (DWP), and kidney, heart, lung and gizzard relative weights, whereas PLM was not significant $(\mathrm{p}>0.05)$ for DW, DWP and the relative weights of internal organs (kidney, liver, heart, lung and gizzard). The interaction of E and PLM was not significant $(\mathrm{p}>0.05)$ for the carcass and all the relative internal organ weights measured.

\section{Table V}

Effect of pawpaw leaf meal and enzyme supplementation on the performance of broiler chickens

\begin{tabular}{|c|c|c|c|c|c|c|}
\hline \multirow[b]{2}{*}{ Diet } & \multicolumn{2}{|c|}{ Body weight gain (g) } & \multicolumn{2}{|c|}{ Feed intake (g) } & \multicolumn{2}{|c|}{ Feed conversion ratio } \\
\hline & 1-3 weeks & 1-6 weeks & 1-3 weeks & 1-6 weeks & 1-3 weeks & 1-6 weeks \\
\hline 1 & $805^{c}$ & $2,583^{b}$ & 1,003 & 3,113 & 1.24 & 1.21 \\
\hline 2 & $832^{a b}$ & $2,722^{a}$ & 1,019 & 3,174 & 1.23 & 1.16 \\
\hline 3 & $813^{b c}$ & $2,678^{a b}$ & 993 & 3,139 & 1.22 & 1.17 \\
\hline 4 & $837^{a}$ & $2,792^{a}$ & 993 & 3,130 & 1.19 & 1.12 \\
\hline SEM & 4.97 & 27.95 & 7.12 & 40.40 & 0.01 & 0.02 \\
\hline$P$ value & 0.03 & 0.02 & 0.59 & 0.97 & 0.35 & 0.41 \\
\hline \multicolumn{7}{|l|}{ ENZ } \\
\hline 0 & $809^{b}$ & $2,631^{b}$ & 998 & 3,126 & 1.23 & 1.18 \\
\hline 0.05 & $835^{\mathrm{a}}$ & $2,757^{a}$ & 1,006 & 3,152 & 1.20 & 1.14 \\
\hline SEM & 4.82 & 26.87 & 10.57 & 66.07 & 0.02 & 0.02 \\
\hline$P$ value & 0.01 & 0.01 & 0.62 & 0.79 & 0.24 & 0.21 \\
\hline \multicolumn{7}{|l|}{ PLM } \\
\hline 0 & 819 & $2,653^{b}$ & 1,011 & 3,144 & 1.24 & 1.18 \\
\hline 50 & 825 & $2,735^{a}$ & 993 & 3,134 & 1.20 & 1.15 \\
\hline SEM & 4.82 & 26.87 & 10.57 & 66.07 & 0.02 & 0.02 \\
\hline$P$ value & 0.34 & 0.05 & 0.27 & 0.92 & 0.19 & 0.27 \\
\hline \multicolumn{7}{|c|}{$\mathrm{ENZ} \times \mathrm{PLM}$} \\
\hline SEM & 6.82 & 38.01 & 14.95 & 93.43 & 0.23 & 0.74 \\
\hline$P$ value & 0.85 & 0.75 & 0.59 & 0.72 & 0.34 & 0.84 \\
\hline
\end{tabular}

Diet 1: control; no addition of pawpaw leaf nor enzyme; Diet 2: enzyme supplement of $0.5 \mathrm{~g} / \mathrm{kg}$ feed, no pawpaw leaf meal; Diet 3: $5 \%$ pawpaw leaf meal, no enzyme; Diet 4: 5\% pawpaw leaf meal + enzyme supplement

$\mathrm{a}, \mathrm{b}, \mathrm{c}$ Means with different superscripts in the same column are significantly different $(\mathrm{p}<0.05)$.

ENZ: enzyme (g/kg); PLM: pawpaw leaf meal $(\mathrm{g} / \mathrm{kg})$; SEM: standard error of means 


\section{Table VI}

Effect of pawpaw leaf meal and enzyme supplementation on the apparent digestibility (\%) of broiler chickens

\begin{tabular}{|c|c|c|c|c|c|}
\hline Diet & DM & $\mathrm{CP}$ & CF & EE & ASH \\
\hline 1 & $79.4^{b}$ & $71.0^{\mathrm{b}}$ & 51.7 & $72.3^{b}$ & $70.0^{b}$ \\
\hline 2 & $88.4^{\mathrm{a}}$ & $78.5^{\mathrm{a}}$ & 55.5 & $78.0^{\mathrm{a}}$ & $76.4^{a}$ \\
\hline 3 & $87.7^{\mathrm{a}}$ & $76.0^{\mathrm{a}}$ & 50.0 & $70.2^{b}$ & $71.2^{b}$ \\
\hline 4 & $88.7^{a}$ & $76.8^{\mathrm{a}}$ & 54.8 & $74.8^{\mathrm{ab}}$ & $74.8^{\mathrm{a}}$ \\
\hline SEM & 1.38 & 1.041 & 1.11 & 1.09 & 0.87 \\
\hline$P$ value & 0.01 & 0.03 & 0.29 & 0.04 & 0.01 \\
\hline \multicolumn{6}{|l|}{ ENZ } \\
\hline 0 & $83.2^{\mathrm{b}}$ & $75.2^{b}$ & 50.9 & $71.3^{b}$ & $70.6^{b}$ \\
\hline 0.05 & $88.6^{a}$ & $79.8^{\mathrm{a}}$ & 55.1 & $76.4^{\mathrm{a}}$ & $75.6^{\mathrm{a}}$ \\
\hline SEM & 1.15 & 1.13 & 1.47 & 1.09 & 0.61 \\
\hline$P$ value & 0.01 & 0.02 & 0.07 & 0.01 & 0.01 \\
\hline \multicolumn{6}{|l|}{ PLM } \\
\hline 0 & $83.9^{b}$ & $75.2^{b}$ & 53.6 & 75.2 & 73.2 \\
\hline 50 & $87.9^{a}$ & $79.8^{\mathrm{a}}$ & 52.4 & 72.5 & 73.0 \\
\hline SEM & 1.15 & 1.13 & 1.47 & 1.09 & 0.61 \\
\hline$P$ value & 0.04 & 0.02 & 0.57 & 0.12 & 0.83 \\
\hline \multicolumn{6}{|c|}{$E N Z \times P L M$} \\
\hline SEM & 1.63 & 1.60 & 2.08 & 1.54 & 0.87 \\
\hline$P$ value & 0.05 & 0.04 & 0.81 & 0.72 & 0.14 \\
\hline
\end{tabular}

Diet 1: control; no addition of pawpaw leaf nor enzyme; Diet 2: enzyme supplement of $0.5 \mathrm{~g} / \mathrm{kg}$ feed, no pawpaw leaf meal; Diet 3: 5\% pawpaw leaf meal, no enzyme; Diet 4: $5 \%$ pawpaw leaf meal + enzyme supplement

$\mathrm{a}, \mathrm{b}$ Means with different superscripts in the same column are significantly different $(\mathrm{p}<0.05)$.

ENZ: enzyme (g/kg); PLM: pawpaw leaf meal (g/kg); DM: dry matter (\%); CP: crude protein (\%); CF: crude fiber (\%); EE: ether extract (\%); SEM: standard error of means

Table VIII shows the effects of PLM and E on hematological indices of broiler chickens. These effects and their interaction were not significant $(\mathrm{p}>0.05)$ for all the hematological parameters except the platelets. The levels of platelets in chickens fed E and/or PLM diets (diets 2, 3 and 4) were higher than those fed the control diet. Platelets significantly $(\mathrm{p}<0.05)$ increased with E. Red blood cells tended to increase $(\mathrm{p}=0.09)$ with $\mathrm{E}$, and the interaction of $\mathrm{E}$ and PLM was significant $(\mathrm{p}<0.05)$ for platelets.

The serum metabolites were similar in the experimental diets except for cholesterol and LDL that were significantly $(\mathrm{p}<0.05)$ higher in the control diet than in the other diets. E significantly $(\mathrm{p}<0.05)$ reduced LDL, whereas PLM significantly $(\mathrm{p}<0.05)$ reduced cholesterol and LDL. The E and PLM interaction was significant $(\mathrm{p}<0.05)$ for LDL (Table IX).

\section{DISCUSSION}

Phytogenic feed additives or phytobiotics are used to boost livestock feed properties with the aim of improving performances. There were slight variations in the chemical composition of PLM in this study compared to values obtained by other authors. For instance in our study, the CP value of PLM (26.14\%) was lower than that of $27.50 \%$ reported by Kadiri et al. (2016). The crude fiber value (16.05\%) recorded for PLM was also higher than that of $5.60 \%$ reported by
Kadiri et al. (2016). These various reports may arise from the natural variability of plant secondary metabolite and chemical compositions (Nahak, 2014; Valenzuela-Grijalva et al., 2017).

The chemical composition of PLM in this study showed that it could be used as a plant protein source and phytogenic feed additive in monogastric nutrition. The presence of alkaloids and flavonoids in PLM indicates its antimicrobial and antioxidant potentials (Shad et al., 2013). Enzyme supplementation has been explored to improve the performance of broilers (Choct, 2006). In our study, multienzyme supplementation improved the BW gain at three and six weeks. This result agrees with that of Hossain et al. (2016) who reported significant growth of broilers when diets were supplemented with microbial enzymes. The improvement in BW gain due to enzyme supplementation in this study may be ascribed in part to the fact that exogenous enzymes could have helped to break down non-starch polysaccharides, antinutritional factors typified by phytates and oxalates with attendant improvement in the biological value of the diet (Choct, 2006). In addition, E could have changed the intestinal environment e.g. viscosity of digesta - leading to better contact between nutrients, endogenous enzymes and absorptive mucosa (Bedford, 1995).

In this study, although the multienzyme supplementation was able to improve the BW gain, it could only numerically improve the feed intake and conversion ratio. This numeric increase in feed intake due to enzyme supplementation may originate from the activity of supplemented enzymes that enhances the availability of certain trace minerals (e.g. $\mathrm{Cu}, \mathrm{Zn}, \mathrm{Mn}$ ) known to stimulate a greater feed intake in broiler chickens (Larbier and Leclercq, 1994). The increased feed intake may also be the consequence of the faster growth of birds caused by $\mathrm{E}$, which results in higher nutritional requirements (Hossain et al., 2016); chicks increase their feed intake in order to meet their nutritional requirements (Shrivastava et al., 1981). However, the present result disagrees in part with Olukosi et al. (2007) who reported an increase in the body weight gain, feed intake and feed efficiency in broilers fed rye- and wheat-based diets with xylanase supplementation. Variations may result in part from nutrient density reductions in control diets, and varied concentrations and compositions of exogenous enzymes used in these studies.

The influence of phytochemicals on the growth performance of farm animals has been linked to their antibacterial activity, stimulation of digestive fluid secretion and decreased intestinal $\mathrm{PH}$, which result in enhanced nutrient utilization efficiency, reduced gut disorder and improved health (Ayodele et al., 2016). In addition, the enzyme (papain) present in PLM has been involved in enhancement of protein digestion and utilization, and as digestive tract cleanser (Oloruntola et al., 2018). According to Kadiri et al. (2016), papain also plays a crucial role in biological processes because of its ability to break down organic molecules made of amino acids (crucial nutrients for growth). This may explain the reasons behind the numeric increase in BW gain of broiler chicks with the $50 \mathrm{~g} / \mathrm{kg}$ PLM diet. Furthermore, the nonsignificant interactive effect of E and PLM suggests that these two factors were independent from one another in broiler chicken nutrition: the presence or activity of one factor did not affect that of the other.

Enzymes are added to animal diets to make up some compounds in feed that cannot be broken down by the digestive enzymes. Enzyme supplementation in this study may have improved dry matter digestibility, crude protein, ether extract and ash digestibility. Protease, one of the components of the multienzymes used in this study might have played a major role in increasing crude protein digestibility by augmenting endogenous production of peptidase and thereby improving the digestibility of dietary protein. In addition, proteases may hydrolyze protein-based antinutrients (Ghazi et al., 2002), thus improving amino acid utilization efficiency and reducing protein turnover in 


\section{Table VII}

Effect of pawpaw leaf meal and enzyme supplementation on the carcass and relative internal organ weight (\% SW) of broiler chickens

\begin{tabular}{|c|c|c|c|c|c|c|c|c|}
\hline Diet & SW & DW & DWP & KID & LIV & HRT & LUN & GIZ \\
\hline 1 & $2,608^{b}$ & 1,282 & 79.8 & 0.66 & $2.53^{\mathrm{ab}}$ & 0.59 & 0.66 & 3.65 \\
\hline 2 & $2,745^{a}$ & 1,374 & 78.9 & 0.52 & $1.92^{\mathrm{C}}$ & 0.53 & 0.63 & 3.28 \\
\hline 3 & $2,702^{a b}$ & 1,366 & 80.2 & 0.71 & $2.76^{\mathrm{a}}$ & 0.55 & 0.66 & 3.73 \\
\hline 4 & $2,812^{\mathrm{a}}$ & 1,383 & 76.3 & 0.65 & $2.00^{b c}$ & 0.51 & 0.64 & 3.39 \\
\hline SEM & 27.55 & 16.93 & 0.87 & 0.04 & 0.13 & 0.22 & 0.03 & 0.10 \\
\hline$P$ value & 0.03 & 0.11 & 0.45 & 0.47 & 0.03 & 0.71 & 0.99 & 0.39 \\
\hline \multicolumn{9}{|l|}{ ENZ } \\
\hline 0 & $2,655^{b}$ & 1,324 & 80.0 & 0.69 & $2.64^{\mathrm{a}}$ & 0.57 & 0.66 & 3.69 \\
\hline 0.05 & $2,779^{a}$ & 1,378 & 77.6 & 0.58 & $1.96^{\mathrm{b}}$ & 0.52 & 0.63 & 3.34 \\
\hline SEM & 26.65 & 19.53 & 1.24 & 0.06 & 0.13 & 0.03 & 0.05 & 0.14 \\
\hline$P$ value & 0.01 & 0.08 & 0.21 & 0.26 & 0.01 & 0.33 & 0.73 & 0.12 \\
\hline \multicolumn{9}{|l|}{ PLM } \\
\hline 0 & 2,677 & 1,328 & 79.3 & 0.59 & 2.22 & 0.56 & 0.65 & 3.46 \\
\hline 50 & 2,757 & 1,374 & 78.3 & 0.68 & 2.38 & 0.53 & 0.65 & 0.57 \\
\hline SEM & 26.65 & 19.53 & 1.24 & 0.05 & 0.13 & 0.03 & 0.05 & 0.14 \\
\hline$P$ value & 0.06 & 0.13 & 0.56 & 0.33 & 0.40 & 0.66 & 0.99 & 0.62 \\
\hline \multicolumn{9}{|c|}{$\mathrm{ENZ} \times \mathrm{PLM}$} \\
\hline SEM & 37.69 & 27.62 & 1.76 & 0.08 & 0.18 & 0.05 & 0.08 & 0.19 \\
\hline$P$ value & 0.73 & 0.21 & 0.41 & 0.65 & 0.67 & 0.81 & 0.97 & 0.92 \\
\hline
\end{tabular}

Diet 1: control; no addition of pawpaw leaf nor enzyme; Diet 2: enzyme supplement of $0.5 \mathrm{~g} / \mathrm{kg}$ feed, no pawpaw leaf meal; Diet 3: $5 \%$ pawpaw leaf meal, no enzyme; Diet 4: $5 \%$ pawpaw leaf meal + enzyme supplement

a, b, c Means with different superscripts in the same column are significantly different $(\mathrm{p}<0.05)$.

SW: slaughtering weight (g/bird); ENZ: enzyme (g/kg); PLM: pawpaw leaf meal (g/kg); DW: dressed weight (g/bird); DWP: dressed weight percentage (\% SW);

KID: kidney (\% SW); LIV: liver (\% SW); HRT: heart (\% SW); LUN: lung (\% SW); GIZ: gizzard (\% SW); SEM: standard error of means

\section{Table VIII}

Effect of pawpaw leaf meal and enzyme supplementation on hematological indices of broiler chickens

\begin{tabular}{|c|c|c|c|c|c|c|c|c|}
\hline Diet & PCV & $\mathrm{HB}$ & $\mathrm{RBC}$ & WBC & LYM & MON & GRA & PLAT \\
\hline 1 & 36.0 & 8.66 & 2.84 & 111.4 & 85.2 & 19.0 & 7.2 & $5.1^{\mathrm{c}}$ \\
\hline 2 & 42.6 & 9.43 & 2.97 & 116.9 & 92.5 & 16.7 & 7.7 & $11.8^{\mathrm{a}}$ \\
\hline 3 & 41.8 & 7.43 & 2.69 & 119.0 & 97.6 & 13.2 & 8.2 & $10.5^{\mathrm{a}}$ \\
\hline 4 & 44.3 & 8.83 & 2.90 & 124.9 & 100.8 & 17.2 & 6.9 & $7.5^{b}$ \\
\hline SEM & 1.63 & 0.38 & 0.05 & 2.54 & 3.94 & 1.24 & 1.03 & 0.83 \\
\hline$P$ value & 0.33 & 0.34 & 2.34 & 0.33 & 0.58 & 0.46 & 0.98 & 0.01 \\
\hline \multicolumn{9}{|l|}{ ENZ } \\
\hline 0 & 38.9 & 8.04 & 2.76 & 115.2 & 91.4 & 16.1 & 7.7 & $7.8^{b}$ \\
\hline 0.05 & 43.5 & 9.13 & 2.94 & 120.9 & 96.7 & 16.9 & 7.3 & $9.7^{a}$ \\
\hline SEM & 2.22 & 0.52 & 0.06 & 3.44 & 5.80 & 1.78 & 1.69 & 0.48 \\
\hline$P$ value & 0.19 & 0.18 & 0.09 & 0.27 & 0.54 & 0.75 & 0.87 & 0.02 \\
\hline \multicolumn{9}{|l|}{ PLM } \\
\hline 0 & 39.3 & 9.04 & 2.90 & 114.1 & 88.9 & 17.8 & 7.4 & 8.5 \\
\hline 50 & 43.1 & 8.13 & 2.79 & 122.0 & 99.2 & 15.2 & 7.6 & 9.0 \\
\hline SEM & 2.22 & 0.52 & 0.06 & 3.44 & 5.83 & 1.78 & 1.69 & 0.48 \\
\hline$P$ value & 0.26 & 0.25 & 0.26 & 0.15 & 0.24 & 0.32 & 0.96 & 0.46 \\
\hline \multicolumn{9}{|c|}{$\mathrm{ENZ} \times \mathrm{PLM}$} \\
\hline SEM & 3.14 & 0.74 & 0.09 & 4.87 & 8.25 & 2.51 & 2.39 & 0.67 \\
\hline$P$ value & 0.53 & 0.68 & 0.64 & 0.96 & 0.80 & 0.24 & 0.73 & 0.00 \\
\hline
\end{tabular}

Diet 1: control; no addition of pawpaw leaf nor enzyme; Diet 2: enzyme supplement of $0.5 \mathrm{~g} / \mathrm{kg}$ feed, no pawpaw leaf meal; Diet 3: 5\% pawpaw leaf meal, no enzyme; Diet 4: $5 \%$ pawpaw leaf meal + enzyme supplement

a, b, c Means with different superscripts in the same column are significantly different $(\mathrm{p}<0.05)$.

ENZ: enzyme (g/kg); PLM: pawpaw leaf meal (g/kg); PCV: packed cell volume (\%); HB: hemoglobin (g/L); RBC: red blood cells (x1012/L); WBC: white blood cells

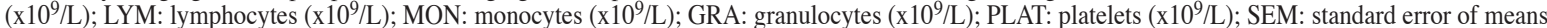


Table IX

Effect of pawpaw leaf meal and enzyme supplementation on serum metabolites of broiler chickens

\begin{tabular}{|c|c|c|c|c|c|c|c|c|}
\hline Diet & TPR & ALB & GLO & $\mathrm{CHO}$ & HDL & LDL & BIL & ALT \\
\hline 1 & 4.16 & 2.89 & 1.27 & $4.99^{\mathrm{a}}$ & 1.93 & $2.72^{\mathrm{a}}$ & 7.10 & 16.61 \\
\hline 2 & 4.19 & 2.98 & 1.20 & $3.60^{\mathrm{ab}}$ & 2.03 & $1.03^{b}$ & 7.14 & 16.10 \\
\hline 3 & 4.15 & 2.94 & 1.21 & $2.89^{b}$ & 1.60 & $1.22^{b}$ & 7.06 & 16.11 \\
\hline 4 & 4.17 & 3.57 & 1.24 & $2.97^{b}$ & 2.13 & $1.11^{b}$ & 7.08 & 16.16 \\
\hline SEM & 0.46 & 0.41 & 1.17 & 0.32 & 0.09 & 0.23 & 0.27 & 0.26 \\
\hline$P$ value & 1.00 & 0.95 & 0.99 & 0.04 & 0.25 & 0.01 & 1.00 & 0.91 \\
\hline \multicolumn{9}{|l|}{ ENZ } \\
\hline 0 & 4.16 & 2.91 & 1.27 & 3.94 & 1.76 & $1.97^{\mathrm{a}}$ & 7.08 & 16.36 \\
\hline 0.05 & 4.18 & 3.27 & 1.20 & 3.28 & 2.08 & $1.07^{\mathrm{b}}$ & 7.11 & 16.13 \\
\hline SEM & 0.77 & 0.67 & 1.21 & 0.33 & 0.12 & 0.18 & 0.44 & 0.43 \\
\hline$P$ value & 0.98 & 0.71 & 1.24 & 0.21 & 0.11 & 0.01 & 0.96 & 0.71 \\
\hline \multicolumn{9}{|l|}{ PLM } \\
\hline 0 & 4.18 & 2.93 & 1.17 & $4.29^{\mathrm{a}}$ & 1.98 & $1.87^{\mathrm{a}}$ & 7.12 & 16.35 \\
\hline 50 & 4.16 & 3.25 & 0.99 & $2.93^{b}$ & 1.86 & $1.16^{b}$ & 7.07 & 16.14 \\
\hline SEM & 0.77 & 0.67 & 1.24 & 0.33 & 0.13 & 0.19 & 0.44 & 0.43 \\
\hline$P$ value & 0.99 & 0.74 & 1.22 & 0.02 & 0.54 & 0.02 & 0.94 & 0.72 \\
\hline \multicolumn{9}{|c|}{$\mathrm{ENZ} \times \mathrm{PLM}$} \\
\hline SEM & 1.09 & 0.95 & 0.28 & 0.47 & 0.17 & 0.26 & 0.62 & 0.60 \\
\hline$P$ value & 0.99 & 0.78 & 0.96 & 0.16 & 0.26 & 0.02 & 0.98 & 0.65 \\
\hline
\end{tabular}

Diet 1: control; no addition of pawpaw leaf nor enzyme; Diet 2: enzyme supplement of $0.5 \mathrm{~g} / \mathrm{kg}$ feed, no pawpaw leaf meal; Diet 3: $5 \%$ pawpaw leaf meal, no enzyme; Diet 4: $5 \%$ pawpaw leaf meal + enzyme supplement

$\mathrm{a}, \mathrm{b}$, Means with different superscripts in the same column are significantly different $(\mathrm{p}<0.05)$.

ENZ: enzyme (g/kg); PLM: pawpaw leaf meal (g/kg); TPR: total protein (g/dl); ALB: albumin (g/dl); GLO: globulin (g/dl); CHO: cholesterol (mg/dl); HDL: high-density lipoprotein (mmol/L); LDL: low-density lipoprotein (mmol/L); BIL: bilirubin ( $\mu \mathrm{mol} / \mathrm{L})$; ALT: alanine amino transferase (U/L); SEM: standard error of means

birds. Phytase improves ileal fat digestibility by reducing endogenous loss and improving dietary nutrient solubility, thereby causing reduction in the undigested fraction (Selle et al., 2010). Supplementary microbial phytase has also been reported to improve bioavailability of dietary phosphorus and other minerals bound to phytates (Um and Palk, 1999). These may be responsible for the increase in ether extract and ash digestibility recorded in this study. The improvement in dry matter and crude protein digestibility due to PLM inclusion in this study may be in part due to the activities of a proteolytic enzyme (papain), an effective natural digestive aid, which aids break down proteins. Worthy of mention is the interaction effect of E and PLM on dry matter and crude protein digestibility in the study; the two factors could synergize one another to achieve optimal digestibility.

The increase in the slaughter weight obtained with E may be due to a better utilization of essential nutrients needed for growth in the birds; the enzymes present in multienzyme supplementation have been reported to enhance nutrient utilization by breaking down materials that interfere with digestion, absorption and utilization of nutrients. In addition, the improvement in the carcass trait due to E which translated to a mere increase in the dressed weight in this study agrees with a report by Ogunsipe et al. (2015) on broiler chickens fed roxazyme G2G supplemented cassava plant meals. Thus, apart from the diet, the carcass yields in broilers are affected by a number of factors, including slaughtering condition, sex, genetics and live weight (Havenstein et al., 2003; Bricket et al., 2007). Comparison of the relative organ weights between treated and untreated groups can be useful to predict the toxic effect of test materials. Liver hypotrophy as a result of enzyme supplementation in this study can be beneficial to health since cases of liver hypertrophy have been linked to increased liver activity through increased digestive enzyme production, when there are herbal supplementation or antinutrients in the plant-based diet (Abou-Elkhair et al., 2014) as in this study. Therefore, in this study the breakage of antinutrients by exogenous enzymes might have normalized the activities of the liver. However, similar kidney, lung and gizzard weights across diets suggest that E, PLM and their interaction did not affect these organ weights.

Hematological indices are used to determine the health status and nutritional state of animals (Aletor and Egberongbe, 1992). The hematological indices determined in the present study were within the normal range reported by Mirtuka and Rawnsley (1997) and were not significantly affected by E and PLM in most cases. This indicates the nutritional adequacy of these factors. However, there was an increase in most erythrocytic indices in E diet. This suggests possible support of this main factor (enzyme) for adequate or normal hematopoiesis. E might enhance the utilization of minerals and vitamins (such as iron, copper, vitamin B, folic acids, among others) needed for blood formation. Several authors (Um and Palk, 1999; Hossain et al., 2016) have reported on improving the bioavailability of minerals (some of which play a significant role in blood formation) by phytase supplementation. White blood cells are part of the immune system which fights infections. Therefore, the tendency to increase in blood parameters was also related to the increase in digestibility in the present study. The increase in WBC and lymphocytes by enzyme supplementation and PLM inclusion in this study may imply that these factors produced an immunomodulatory effect in the birds, as reported by Oloruntola et al. (2016b).

Platelets, which are produced by the bone marrow, help in blood clotting and wound healing. The significant numerical increase in platelets in broiler chicks fed E and PLM diets, respectively, further 
confirmed the health protection effect against excessive blood loss in the birds. In addition, the significant interactive effect of E and PLM shows that combining these factors might promote healing and prevent blood loss. Some phytochemicals such as saponin present in leaf meals have been reported to exert a hypocholesterolemic effect and reduce gut cholesterol uptake through intralumenal physicochemical interaction (Yilkal, 2015). This may be responsible for the decrease in cholesterol in PLM inclusive diets, suggesting that PLM have hypocholesterolemic properties. In addition, the decrease in LDL due to the two main factors (E and PLM) and cholesterol level due to PLM inclusion further support the wholesomeness of the dietary treatment in promoting health in broiler chickens. This result agrees with Oloruntola et al. (2016b), who reported a decrease in serum cholesterol concentration when including enzyme and Alchornea leaf meal in the diet of broiler chickens.

\section{- CONCLUSION}

Enzyme supplementation $(0.5 \mathrm{~g} / \mathrm{kg})$ improved the BW gain of broilers. It also improved DM, CP, EE, and ash digestibility, whereas PLM inclusion $(50 \mathrm{~g} / \mathrm{kg}$ ) enhanced DM and CP digestibility. E improved SW in broiler chickens. No negative effects of enzymes nor of PLM on the other studied parameters were observed. Enzyme supplementation $(0.05 \%)$ in broiler chickens improved their performance, whereas enzyme supplementation (0.05\%) and PLM inclusion (5\%) promoted nutrient digestibility and health benefits.

\section{REFERENCES}

Abou-Elkhair R., Ahmed H.M., Selim S., 2014. Effect of pepper (Piper nigrum), tumeric powder (Curcuma longa) and coriander seeds (Coriandrum sativum) and their combinations as feed additives on growth performance, carcass traits, some blood parameters and humoral immune response of broiler chickens. Asian Australas. J. Anim. Sci., 27 (6): 847-854, doi: 10.5713/ ajas.2013.13644

Aletor V.A., Egberongbe O., 1992. Feeding differently processed soya bean. Part 2: An assessment of haematological responses in chickens. Nahrung, $\mathbf{3 6}$ : 364-369, doi: $10.1002 /$ food.19920360406

AOAC, 1990. Official methods of analysis, Vol. 1, 15th Edn. AOAC, Arlington, VA, USA

Ayodele S.O., Oloruntola O.D., Agbede J.O., 2016. Effect of Alchornea cordifolia leaf meal inclusion and enzyme supplementation on performance and digestibility of rabbits. World Rabbit Sci., 24: 201-206, doi: 10.4995/ wrs.2016.3933

Bedford M.R., 1995. Mechanism of action and potential environmental benefits from the use of feed enzymes. Anim. Feed Sci. Technol., 53: 145-155, doi: 10.1016/0377-8401(95)02018-U

Bedford M., 2000. Removal of antibiotic growth promoters from poultry diets: implications and strategies to minimise subsequent problems. World Poult. Sci. J., 56 (4): 347-365, doi: 10.1079/WPS20000024

Brickett K.E., Dahiya J.P., Classen H.L., Gomis S., 2007. Influence of dietary nutrient density, feed form, and lighting on growth and meat yield of broiler chickens. Poult. Sci, 86: 2172-2181, doi: 10.1093/ps/86.10.2172

Choct M., 2006. Enzymes for the feed industry, past, present and future. World Poult. Sci. J., 6 (2): 5-15, doi: 10.1079/WPS200480

Day R.A., Underwood A.L., 1986. Qualitative analysis, 5th Edn. London, Prentice Hall, UK / New Delhi, India, 701 p.

Falçao-e-Cunha L., Castro-Solla L., Maertens L., Marounek M., Pinheiro V., Freire J.L., Mourao J.L., 2007. Alternatives to antibiotic growth promoters in rabbit feeding: a review. World Rabbit Sci., 15: 127-140, doi: 10.4995/ wrs.2007.597

García M., Lázaro R., Latorre M.A., Gracia M.I., Mateos G.G., 2008. Influence of enzyme supplementation and heat processing of barley on digestive traits and productive performance of broilers. Poult. Sci., 87: 940-948, doi: 10.3382/ps.2007-00266

Ghazi S., Rooke J.A., Galbraith H., Bedford M.R., 2002. The potential for the improvement of the nutritive value of soya-bean meal by different proteases in broiler chicks and broiler cockerels. Br. Poult. Sci., 43: 70-77, doi: 10.1080/00071660120109935

Harborne J.B., 1973. Phytochemical methods. Chapman and Hall, London, UK, 49-188

Havenstein G.B., Ferket P.R., Qureshi M.A., 2003. Carcass composition and yield of 1957 versus 2001 broilers when fed representative 1957 and 2001 broiler diets. Poult. Sci., 82: 1509-1518, doi: 10.1093/ps/82.10.1509

Hossain M.A., Iji P.A., Islam A.M.F., 2016. Gross responses and apparent digestibility of amino acid and mineral in broiler chickens fed vegetablebased starter diets supplemented with microbial enzymes. Turkish J. Vet. Anim. Sci., 40: 1-7, doi: 10.3906/vet-1504-65

Kadiri O., Olawoye B., Fawale O.S., Adalumo O.A., 2016. Nutraceutical and antioxidant properties of the seeds, leaves and fruits of Carica papaya: Potential relevance to human diet, the food industry and the pharmaceutical industry. A review. Turkish J. Agric. Food Sci. Tech. 4 (12): 1039-1052, doi: 10.24925/turjaf.v4i12.1039-1052.569

Kahkonen M.P., Hopia A.I., Heinonen M., 2001. Berry phenolics and their antioxidant activity. J. Agric. Food Chem., 49: 4076-4082, doi: 10.1021/ jf010152t

Lambs G.N., 1981. Manual of veterinary laboratory technique. CIBA-GEIGY, Nairobi, Kenya, 96-97 p.

Larbier M.L., Wiseman J., Leclercq B., 1994. Nutrition and feeding of poultry. Nottingham University Press, Loughborough, UK, 101-118

Lázaro R., García M., Araníbar M.J., Mateos G.G., 2003. Effect of enzyme addition to wheat, barley and rye-based diets on nutrient digestibility and performance of laying hens. Br. Poult. Sci., 44: 256-265, doi: 10.1080/0007166031000085616

Mateos G.G., Rebollar P.G., de Blass C., 2010. Minerals, vitamins and additives. In: Nutrition of the rabbit (Eds. de Blass C., Wise J.). CAB-I, Wallingford, UK, 151-162, doi: 10.1079/9781845936693.0119

Mirtuka B.M., Rawnsley H.N., 1977. Clinical biochemical and haematological references values in normal experimental animals. Masson, New York, USA, $270 \mathrm{p}$.

Nahak G., Suar M., Sahu R.K., 2014. Antioxidant potential and nutritional values of vegetables: A Review. Res. J. Med. Plant., 8 (2): 50-81

Ogunsipe M.H., Adejumon J.O., Agbede J.O., Asaniyan E.K., 2015. Effect of roxazyme $\mathrm{G} 2 \mathrm{G}$ supplementation on cassava plant meal fed to broiler chickens. Livest. Res. Rural Dev., 27 (12), www.Irrd.org/lrrd27/12/ ogun27240.htm

Oloruntola O.D., Agbede J.O., Onibi G.E., Igbasan F.A., 2016a. Replacement value of rumen liquor fermented cassava peels for maize in growing rabbit. Arch. Zootec., 65 (249): 89-97

Oloruntola O.D., Ayodele S.O., Adeyeye S.A., Ogunsipe M.H., Daramola O.T., Ayedun E.S., 2018. Effect of pawpaw leaf meal and multi-enzyme supplementation in the diet on performance, digestibility, and oxidative enzyme status of rabbits. J. Basic Appl. Zool., 79: 26, doi: 10.1186/s41936018-0039-1

Oloruntola O.D., Ayodele S.O., Agbede J.O., Oloruntola D.A., 2016b. Effect of feeding broiler chickens with diets containing Alchornea cordifolia leaf meal and enzyme supplementation. Arch. Zootec., 65 (252): 489-498

Olukosi O.A., Bedford M.R., Adeola O., 2007. Xylanase in diets for growing swine and broiler chicks. Can. J. Ani. Sci., 87: 227-235, doi: 10.4141/ CJAS06005 
Selle P.H., Ravindran V., Cowieson A.J., Bedford M.R., 2010. Phytate and phytase. In: Enzymes in farm animal nutrition (Eds. Michael R.B., Gary G.P.). CABI, Wallingford, UK, 160-205, doi: 10.1079/9781845936747.0054

Shad M.A. Nawaz H., Rehma T., Ikram M., 2013. Determination of biochemicals, phytochemicals and antioxidative properties of different part of Cichorium intybus L.: A comparative study. J. Anim. Plant Sci., 23 (4): 10601066

Shrivastava H.P., Sadagopan V.R., Johri T.S., Chand S., 1981. Sunflower seed meal for poultry-a review. Indian Poult. Gazette, 65: 100-112

Um J.S., Palk I.K., 1999. Effect of microbial phytase supplementation on egg production, egg shell quality and mineral retention of laying hens fed different levels of phosphorus. Poult. Sci., 78: 75-79, doi: 10.1093/ps/78.1.75
Valenzuela-Grijalva N.V., Pinelli-Saavedra A., Muhlia-Almazan A. Dominguez-Diaz D., Gonzalez-Rios H., 2017. Dietary inclusion effects of phytochemicals as growth promoters in animal production. J. Anim. Sci. Technol., 58: 8, doi: 10.1186/s40781-017-0133-9

Van-Burden T.P., Robinson W.C., 1981. Formation of complexes between protein and tannin acid. J. Agric. Food Chem., 1: 77

Vogtman H., Pfirter P., Prabuck A.L., 1975. A new method of determining metabolisability energy and digestibility of fatty acids in broiler diets. Br. Poult. Sci., 16: 531-534, doi: 10.1080/00071667508416222

Wheeler E.L., Ferrel R.E., 1971. A method for phytic acid determination in wheat and wheat fractions. Cereal Chem., 48: 312- 316

Yilkal T., 2015. Important anti-nutritional substances and inherent toxicants of feeds. Food Sci. Quality Manag., 36: 40-47

\section{Résumé}

Oloruntola O.D., Ayodele S.O., Oloruntola D.A. Effet de la farine de feuilles de payaye (Carica papaya) et des enzymes alimentaires sur les performances, la digestibilité, la composition de la carcasse et du sang chez le poulet de chair

Des enzymes exogènes et des additifs alimentaires phytogènes sont proposés en alternative aux antibiotiques utilisés comme promoteurs de croissance dans la production de volaille. Cette étude a évalué l'effet de l'incorporation de farine de feuilles de papaye (FFP) et de la supplémentation en enzymes (E) dans le régime alimentaire des poulets de chair. Au total, 288 poulets de chair Arbor Acre d'un jour ont été utilisés. Quatre régimes alimentaires ont été formulés pour être isocaloriques et isoprotéiques : régime 1 , témoin $(0 \% \mathrm{FFP}, 0 \% \mathrm{E})$, régime 2 $(0 \% \mathrm{FFP}, 0,05 \% \mathrm{E})$, régime $3(5 \% \mathrm{FFP}, 0 \% \mathrm{E})$ et régime 4 ( $5 \% \mathrm{FFP}, 0,05 \% \mathrm{E})$. Chaque régime a été répliqué six fois avec 12 poulets dans chaque lot. $\mathrm{E}$ a amélioré $(\mathrm{p}<0,05)$ le gain de poids à trois semaines. La digestibilité de la matière sèche (MS), des protéines brutes $(\mathrm{PB})$, des matières grasses et des cendres a été améliorée $(p<0,05)$ avec $E$, alors que I'incorporation de FFP a augmenté $(p<0,05)$ la digestibilité de la MS et des PB. L'interaction E x FFP a été significative ( $p$ $<0,05)$ pour la digestibilité de la MS et des PB. E a amélioré ( $p$ $<0,05)$ le poids à l'abattage et a diminué le poids du foie. Les plaquettes sanguines ont varié selon les régimes et ont augmenté $(p<0,05)$ avec $E$. $E$ a réduit $(p<0,05)$ les lipoprotéines de basse densité (LDL), alors que FFP a réduit $(p<0,05)$ le cholestérol et les LDL. En conclusion, l'association de $E$ et de FFP a amélioré la croissance des poulets, et la supplémentation en enzymes ou en FFP serait bénéfique pour la santé des poulets.

Mots-clés : poulet de chair, alimentation des animaux, papaye, enzyme, performance animale, Nigeria

\section{Resumen}

Oloruntola O.D., Ayodele S.O., Oloruntola D.A. Efecto de la harina de hoja de papaya (Carica papaya) y de las enzimas exógenas en la dieta sobre el rendimiento de los pollos de engorde, la digestibilidad y la composición de la carcasa y de la sangre

Se proponen enzimas exógenas y aditivos fitogénicos para alimentos como alternativas a los antibióticos promotores de crecimiento en la producción avícola. Este estudio evaluó el efecto de la inclusión de la harina de hoja de papaya (HHP) y la suplementación con enzimas (E) en la dieta de pollos de engorde. En total se utilizaron 288 pollos de engorde de Arbor-Acre de un día de edad. Se formularon cuatro dietas para ser isocalóricas e isonitrógenas: dieta 1, control $(0 \%$ $\mathrm{HHP}, 0 \% \mathrm{E})$, dieta $2(0 \% \mathrm{HHP}, 0,05 \% \mathrm{E})$, dieta $3(5 \% \mathrm{HHP}$ $0 \% \mathrm{E})$ y dieta $4(5 \% \mathrm{HHP}, 0,05 \% \mathrm{E})$. Cada dieta se repitió seis veces con 12 pollos en cada lote. A las tres semanas $E$ mejoró $(p<0,05)$ el aumento de peso corporal. La digestibilidad de la materia seca (MS), proteína cruda (PC), extracto de éter y ceniza ha sido mejorada $(p<0,05)$ con $E$, mientras que la inclusión de HHP produjo $(p<0,05)$ un aumento en la digestibilidad de la MS y la PC. El efecto E x HHP fue significativo $(p<0,05)$ para la digestibilidad de la MS y la PC. El peso de sacrificio mejoró con $E(p<0,05)$ y redujo el peso del hígado. Las plaquetas variaron con las dietas y aumentaron $(p<0,05)$ con la suplementación con enzimas. E redujo $(p<0,05)$ las lipoproteínas de baja densidad (LDL), mientras que HHP redujo $(p<0,05)$ el colesterol y LDL. En conclusión, la asociación de E y HHP mejoró el crecimiento del pollo, y la inclusión de E o HHP debería beneficiar la salud del pollo.

Palabras clave: pollo de engorde, alimentación de los animales, papayas, enzimas, desempeño animal, Nigeria 
